\title{
Phosphate adsorption from sewage sludge filtrate using zinc-aluminum layered double hydroxides
}

\author{
Xiang Cheng a ${ }^{\mathrm{a}}$, Xinrui Huang ${ }^{\mathrm{a}}$, Xingzu Wang ${ }^{\mathrm{a}}$, Bingqing Zhao ${ }^{\mathrm{b}}$, Aiyan Chen ${ }^{\mathrm{a}}$, Dezhi Sun ${ }^{\mathrm{a}, \mathrm{c}, *}$ \\ a School of Municipal \& Environmental Engineering, Harbin Institute of Technology, 202 Haihe Road, 150090 Harbin, China \\ ${ }^{\mathrm{b}}$ Research Center for Eco-Environmental Science, Chinese Academy of Sciences, 18 Shuangqing Road, 100085 Beijing, China

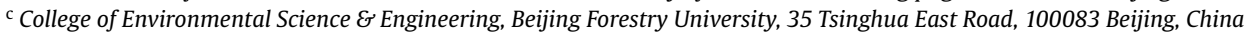

\section{A R T I C L E I N F O}

\section{Article history:}

Received 26 August 2008

Received in revised form 9 April 2009

Accepted 13 April 2009

Available online 19 April 2009

\section{Keywords:}

Phosphate adsorption

$\mathrm{Zn}-\mathrm{Al}$ layered double hydroxides

Calcination

Desorption and regeneration

Sewage sludge filtrate

\begin{abstract}
A B S T R A C T
A series of layered double hydroxides (LDHs) with different metal cations were synthesized to remove phosphate in waste sludge filtrate from a municipal wastewater treatment plant for phosphorus recovery and to help control eutrophication. The highest phosphate adsorption capacity was obtained by using $\mathrm{Zn}-\mathrm{Al}-2-300$, that is LDHs with $\mathrm{Zn} / \mathrm{Al}$ molar ratio of 2 and calcined at $300^{\circ} \mathrm{C}$ for $4 \mathrm{~h}$. Circumneutral and mildly alkaline waters appeared suitable for the possible application of $\mathrm{Zn}-\mathrm{Al}$ LDHs due to the amphoteric nature of aluminum hydroxide. Phosphate adsorption from the sludge filtrate by the LDHs followed pseudo-second-order kinetics, and the adsorption capacity at equilibrium was determined to be $\sim 50 \mathrm{mg} \mathrm{P} / \mathrm{g}$. Adsorption isotherms showed that phosphate uptake in this study was an endothermic process and had a good fit with a Langmuir-type model. The absorbed phosphate can be effectively desorbed (more than $80 \%$ ) from $\mathrm{LDHs}$ particles by a $5 \mathrm{wt} \% \mathrm{NaOH}$ solution. The regeneration rate of used $\mathrm{LDHs}$ was $\sim 60 \%$ after six cycles of adsorption-desorption-regeneration.
\end{abstract}

(C) 2009 Elsevier B.V. All rights reserved.

\section{Introduction}

Waste streams from industrial, agricultural and household activities contain considerable amount of soluble phosphate, and its discharge to receiving waters could result in eutrophication of rivers, lakes and bays [1]. Currently biological nutrient removal processes are employed as the main methods for phosphate separation from wastewaters. However, the application of these methods does not perfectly resolve the problem because of environmental risks and safety concerns in disposal of these sludges containing condensed phosphate, heavy metals and microorganisms.

On the other hand, phosphorus is essential for all forms of life. Phosphorus plays an important role in DNA/RNA molecules and is also related to cellular energy transport via ATP. Unfortunately, phosphorus as a resource is nonrenewable and nonreplaceable. Under present technological and economic conditions the known supply of phosphorus is estimated to meet the demand for only around one century; this includes large amounts found in low-grade rock [2]. Most of phosphorus in nature will end up in deep marine sediments, reentering the cycle probably after millions of years.

* Corresponding author at: School of Municipal \& Environmental Engineering, Harbin Institute of Technology, 202 Haihe Road, 150090 Harbin, China. Tel.: +86106233 6596; fax: +861062336596.

E-mail address: sdzlab@126.com (D. Sun).
Therefore, it is urgent to protect, recover and reuse this limited resource for the sustainable development of the globe.

Chemical precipitation has been well documented as a popular technology for phosphate recovery from wastewater in pilotand a few full-scale evaluations [3,4]. It is fairly controllable and will produce high-quality of phosphate precipitates, typically struvite. Precipitation incurs a cost for treatment chemicals and also a large volume of chemical sludge, which becomes a disposable problem. More recently some researchers studied the feasibility of phosphate adsorption from phosphate-rich streams. The various adsorbents used include industrial materials and byproducts (i.e., iron oxide tailings [5], fly ash [6], blast furnace slag [7] and red mud [8]), natural or synthetic minerals (i.e., goethite $[9,10]$, dolomite [11] and alunite [12]), metal oxide/hydroxide (i.e., aluminum oxide, iron oxide, zirconium oxide [13] and zirconium hydroxide [14]) and other materials (i.e., ion exchange resin [15]).

Layered double hydroxides (LDHs), also called hydrotalcite-like compound or anionic clay, have received wide attention as an effective adsorbent. The formula can be normally expressed as $\left[\mathrm{M}_{1-x}{ }^{2+} \mathrm{M}_{x}{ }^{3+}(\mathrm{OH})_{2}\right]\left[\mathrm{A}^{n-}\right]_{x / n} \cdot y \mathrm{H}_{2} \mathrm{O}$, where $\mathrm{M}^{2+}$ and $\mathrm{M}^{3+}$ are di- and trivalent metal cations in the octahedral positions of the positively charged brucite-like layers, $\mathrm{A}^{n-}$ is the incorporated anions in the interlayer space along with water molecules for charge neutrality and structure stability, and x normally ranges from 0.17 to 0.33 [16]. Due to the high charge density of the sheets from $\mathrm{M}^{2+}$ substitution by $\mathrm{M}^{3+}$ and the exchangeability of the interlayer anions 
as well, LDHs have been employed in several studies for removing phosphate in different environment, such as phosphate solutions [13,17-19], drain effluent [20] and seawater [21].

In secondary/enhanced biological processes in municipal sewage works, various forms of phosphorus in water become concentrated in the waste sludge. When exposed to anaerobic conditions, the assimilated phosphorus tends to be released once again, giving rise to a higher concentration of soluble phosphate in the sludge filtrate. The Institute for European Environmental Policy estimated that full application of the Urban Waste Water Treatment Directive 91/271 (EU legislation) would result in a total or around 220-240,000 tonnes phosphates $(P)$ per year being transferred into and removed via sewage sludges [22]. However, to our knowledge, there is no report as yet available on phosphate adsorption from sewage sludge filtrate by LDHs, probably because the high levels of suspended solids in that stream easily clogged the experimental adsorption columns. In the present study, we used magnetic particles-amended LDHs to remove phosphate in sludge filtrate from a sewage treatment plant. The particles were then effectively separated by a magnetic-field for phosphate recovery. Furthermore, factors influencing the adsorption and recovery processes were investigated.

\section{Materials and methods}

\subsection{Preparation of $L D H s$}

A series of LDHs were synthesized by coprecipitation method using various divalent ( $\mathrm{Mg}, \mathrm{Zn}, \mathrm{Cu}, \mathrm{Ni}$ and $\mathrm{Co}$ ) and trivalent ( $\mathrm{Al}, \mathrm{Fe}$ ) metal cations, and were abbreviated as M(II)-M(III). 200-ml solutions of mixed metal chlorides were prepared in a $500-\mathrm{ml}$ beaker containing $0.5 \mathrm{M}$ of $\mathrm{M}(\mathrm{II})$ and variable amount of $\mathrm{M}(\mathrm{III})$ (according to the desired $\mathrm{M}(\mathrm{II}) / \mathrm{M}(\mathrm{II})$ ratios). $\mathrm{Fe}_{3} \mathrm{O}_{4}$ powder was introduced as magnetic core for $\mathrm{LDHs}$ particle formation. Under vigorous mechanical stirring, a $20 \% \mathrm{NaOH}$ solution was then added dropwise through a peristaltic pump to reach final $\mathrm{pH}$ of $9.0 \pm 0.2$. The synthesis was performed at $80^{\circ} \mathrm{C}$ in a water thermostat, followed by aging for $18 \mathrm{~h}$ at the same temperature. The resulting slurry was filtered and rinsed with deionized water thoroughly until no chloride ion was detected. After drying at $80^{\circ} \mathrm{C}$ overnight, the precipitate was ground to $\sim 100$-mm particles. A portion of the obtained LDHs particles was calcined in an atmosphere of high-purity nitrogen for $4 \mathrm{~h}$ to study its effect on the adsorption capacity of the resulting particles. All chemicals used were at least analytical reagent grade except the $\mathrm{Fe}_{3} \mathrm{O}_{4}$ powder being chemical grade.

\subsection{Phosphate adsorption from sewage sludge filtrate}

Adsorption assays were carried out in a thermostatic shaker at room temperature. A mass of $0.02 \mathrm{~g}$ of LDHs particles were added to 117-mL glass serum vials with $50 \mathrm{~mL}$ of sludge filtrate (from Taiping municipal wastewater treatment plant, Harbin, China) and sealed with butyl rubber stoppers. The water quality of the sludge filtrate is shown in Table 1. No pH adjustment (except during the assays of $\mathrm{pH}$ effect) or other adjustments were made to the filtrate. After $24 \mathrm{~h}$ adsorption, the supernatant was immediately filtered through a $0.45-\mu \mathrm{m}$ membrane for complete particle removal. The resulting liquid was used to determine the residual phosphate and then calculate the adsorption capacity of the LDHs. LDHs-free vials were prepared as a control to observe non-adsorptive removal (degradation) of phosphate in the water. All assays were conducted in triplicate. Phosphate adsorption kinetics were investigated similarly, except that $0.1 \mathrm{~g}$ of LDHs and $250 \mathrm{~mL}$ of the sludge filtrate were used, and the phosphate concentration in liquid was followed for $72 \mathrm{~h}$.
Table 1

Characteristics of sludge filtrate from Taiping municipal wastewater treatment plant, Harbin, China.

\begin{tabular}{llll}
\hline Parameter & Sludge filtrate & Parameter & Sludge filtrate \\
\hline $\mathrm{pH}$ & $6.80 \pm 0.00$ & $\mathrm{Na}^{+}, \mathrm{mg} / \mathrm{L}$ & $83.65 \pm 0.19$ \\
$\mathrm{SS}, \mathrm{mg} / \mathrm{L}$ & $3.82 \pm 0.00$ & $\mathrm{~K}^{+}, \mathrm{mg} / \mathrm{L}$ & $44.66 \pm 0.05$ \\
$\mathrm{COD}, \mathrm{mg} / \mathrm{L}$ & $514.62 \pm 6.24$ & $\mathrm{Al}^{3+}, \mathrm{mg} / \mathrm{L}$ & $0.06 \pm 0.00$ \\
$\mathrm{PO}_{4}{ }^{3-}, \mathrm{mg} / \mathrm{L}$ & $20.00 \pm 4.10$ & $\mathrm{Ca}^{2+}, \mathrm{mg} / \mathrm{L}$ & $105.80 \pm 0.60$ \\
$\mathrm{NO}_{2}{ }^{-}, \mathrm{mg} / \mathrm{L}$ & $\mathrm{ND}^{\mathrm{a}}$ & $\mathrm{Cu}^{2+}, \mathrm{mg} / \mathrm{L}$ & $\mathrm{ND}^{\mathrm{a}}$ \\
$\mathrm{NO}_{3}{ }^{-}, \mathrm{mg} / \mathrm{L}$ & $\mathrm{ND}^{\mathrm{a}}$ & $\mathrm{Fe}, \mathrm{mg} / \mathrm{L}$ & $0.24 \pm 0.00$ \\
$\mathrm{SO}_{4}{ }^{2-}, \mathrm{mg} / \mathrm{L}$ & $112.53 \pm 0.42$ & $\mathrm{Mg}^{2+}, \mathrm{mg} / \mathrm{L}$ & $27.22 \pm 0.09$ \\
$\mathrm{Cl}^{-}, \mathrm{mg} / \mathrm{L}$ & $81.44 \pm 0.50$ & $\mathrm{Mn}^{2+}, \mathrm{mg} / \mathrm{L}$ & $1.34 \pm 0.01$ \\
$\mathrm{NH}_{4}{ }^{+}, \mathrm{mg} / \mathrm{L}$ & $84.34 \pm 4.82$ & $\mathrm{Zn}^{2+}, \mathrm{mg} / \mathrm{L}$ & $0.01 \pm 0.00$ \\
\hline
\end{tabular}

a ND: non-detectable.

\subsection{Effect of $\mathrm{pH}$ on phosphate adsorption}

The $\mathrm{pH}$ dependence of phosphate adsorption by LDHs was evaluated in batch assays with sludge filtrates from $\mathrm{pH} 2-12$. The $\mathrm{pH}$ was adjusted using $1 \mathrm{M} \mathrm{HCl} / \mathrm{NaOH}$ solution. The phosphate residue in the solution was measured and the concentrations of metal ions were analyzed to estimate the LDH dissolution.

\subsection{Study of adsorption isotherm}

Adsorption isotherms were obtained by mixing known amounts of LDHs particles with $250 \mathrm{~mL}$ of sludge filtrates in 583-ml glass infusion bottles and stirring at fixed temperatures. Residual phosphate was measured after $72 \mathrm{~h}$ when adsorption equilibrium was nearly achieved based on the foregoing investigation. Isotherms of phosphate adsorption in $\mathrm{KH}_{2} \mathrm{PO}_{4}$ solutions (with the same phosphorus concentration as in the sludge filtrate: $20 \mathrm{mg}$ P/L) were also produced for comparison.

\subsection{Study of $L D H s$ recovery and phosphate desorption}

Phosphate-loaded LDHs were obtained by mixing Zn-Al-2-300 ( $\mathrm{Zn}-\mathrm{Al} \mathrm{LDHs}$ with $\mathrm{Zn} / \mathrm{Al}$ molar ratio of 2 , calcined at $300^{\circ} \mathrm{C}$ ) with sludge filtrate at room temperature for $24 \mathrm{~h}$. The particles were separated from the solution by imposing a magnet field, then washed in deionized water several times, and dried at $80^{\circ} \mathrm{C}$. An equal amount of the recovered solids were added to three types of desorbent solutions over a range of concentrations (Table 2) to evaluate phosphate desorption. After $24 \mathrm{~h}$ of interaction at room temperature, the supernatant was sampled to determine the extent of phosphate release. The resulting LDHs particles were again separated, washed, dried and then regenerated by calcination. The cycle of adsorption, desorption and regeneration was performed seven times using a $5 \%$ $\mathrm{NaOH}$ solution as a desorbent.

Table 2

Selection of solutions for phosphate desorption from LDHs particles.

\begin{tabular}{|c|c|c|c|}
\hline Desorption solutions & Desorption rate (\%) & $\mathrm{Zn}^{2+}(\mathrm{mg} / \mathrm{L})$ & $\mathrm{Al}^{3+}(\mathrm{mg} / \mathrm{L})$ \\
\hline $1 \%(w / v) \mathrm{NaOH}$ & 20.58 & 23.90 & 16.75 \\
\hline $2 \%(w / v) \mathrm{NaOH}$ & 37.99 & 54.00 & 34.18 \\
\hline $3 \%(\mathrm{w} / \mathrm{v}) \mathrm{NaOH}$ & 52.27 & 65.40 & 33.70 \\
\hline $5 \%(w / v) \mathrm{NaOH}$ & 87.57 & 85.00 & 36.12 \\
\hline $10 \%(w / v) \mathrm{NaOH}$ & 89.34 & 333.10 & 61.17 \\
\hline $20 \%(w / v) \mathrm{NaOH}$ & 91.24 & 426.60 & 66.12 \\
\hline $5 \%(\mathrm{w} / \mathrm{v}) \mathrm{NaCl}$ & 7.56 & 3.20 & 30.54 \\
\hline $10 \%(w / v) \mathrm{NaCl}$ & 10.34 & 8.70 & 30.49 \\
\hline $20 \%(\mathrm{w} / \mathrm{v}) \mathrm{NaCl}$ & 21.17 & 9.50 & 30.19 \\
\hline $5 \%(\mathrm{w} / \mathrm{v}) \mathrm{NaCO}_{3}$ & 40.34 & 41.34 & 20.11 \\
\hline $10 \%(\mathrm{w} / \mathrm{v}) \mathrm{NaCO}_{3}$ & 84.22 & 100.35 & 43.06 \\
\hline
\end{tabular}


The recovery rate $\left(R_{\mathrm{rec}}\right)$, desorption rate $\left(R_{\mathrm{des}}\right)$ and regeneration rate $\left(R_{\mathrm{reg}}\right)$ were estimated using the following equations:

$R_{\mathrm{rec}(i)}=\frac{L_{(i+1)}}{L_{(i)}} \times 100$

$R_{\operatorname{des}(i)}=\frac{Q_{\operatorname{des}(i)}}{Q_{\mathrm{ads}(i)}} \times 100$

$R_{\mathrm{reg}(i)}=\frac{Q_{\mathrm{ads}(i+1)}}{Q_{\mathrm{ads}(1)}} \times 100$

where $L_{(i)}$ : the amount of the adsorbent used in the $i$ th adsorption assay (g); $Q_{\text {ads }(i)}$ : phosphate uptake in the $i$ th adsorption operation (mg P/g adsorbent); $Q_{\operatorname{des}(i)}$ : phosphate desorbed in the $i$ th desorption operation ( $\mathrm{mg} \mathrm{P} / \mathrm{g}$ adsorbent).

\subsection{Analysis}

\subsubsection{Characterization of $\mathrm{LDHs}$}

Metal ions were analyzed by inductively coupled plasma optical emission spectrometry (ICP-OES, Optima 5300DV, PerkinElmer, USA). Crystal phases of LDHs were determined using an X-ray diffractometer (D/Max-RB, Rigaku, Japan) with CuK $\alpha$ radiation and operating at $45 \mathrm{kV}$ and $45 \mathrm{~mA}$. Samples were prepared as finely pressed LDHs powder in an aluminum holder. XRD patterns were collected over a $2 \theta$ from $10^{\circ}$ to $90^{\circ}$ in a scan rate of $5^{\circ} / \mathrm{min}$. Thermogravimetry and differential thermal analysis (TG-DSC) were carried out on a STA449C instrument (NETZSCH, Germany). A mass of $4.675 \mathrm{mg}$ of LDHs particles in an open $\mathrm{Al}_{2} \mathrm{O}_{3}$ crucible were heated from 35 to $1000^{\circ} \mathrm{C}\left(10^{\circ} \mathrm{C} / \mathrm{min}\right)$ in an $\mathrm{Ar}$ atmosphere at a flow rate of $30 \mathrm{~mL} / \mathrm{min}$.

\subsubsection{Phosphate measurement}

Water samples were filtered through $0.45-\mu \mathrm{m}$ membranes to remove suspended solids. The filtrate was then used to determine the concentration of soluble phosphate by the molybdenum blue method [23]. No pH adjustment was conducted except in desorption assays where the $\mathrm{pH}$ value of the samples was adjusted to $7.0 \pm 0.1$ due to their strong alkalinity.

\section{Results and discussion}

\subsection{Parameters affecting phosphate adsorption from sewage} sludge filtrate by $\mathrm{LDHs}$

\subsubsection{Metal composition}

LDHs particles prepared with various metal cations were subjected to phosphate adsorption assays. As shown in Fig. $1, \mathrm{Zn}-\mathrm{Al}$ LDHs had the highest adsorption capacity of up to $24.98 \mathrm{mg} \mathrm{P} / \mathrm{g}$ adsorbent in the sewage sludge filtrate with an initial phosphate concentration of $16.06 \mathrm{mg} \mathrm{P} / \mathrm{L}$, followed closely by $\mathrm{Mg}-\mathrm{Fe}$ and $\mathrm{Zn}-\mathrm{Fe}$ particles. Low phosphate uptake was observed when $\mathrm{Cu}$, $\mathrm{Ni}$ or $\mathrm{Co}$ was the divalent cation for LDHs synthesis. The results found here differ from those in similar documents. Das et al. [19] reported that $\mathrm{Mg}-\mathrm{Al}$ LDHs was the most efficient adsorbent for phosphate removal in a potassium dihydrogen phosphate solution. Chitrakar et al. [21] suggested that a Mg-Mn type and its heat-treated materials were more effective for adsorbing phosphate from seawater. In fact, phosphate uptake by layered double hydroxides in an aquatic environment, especially real waters, is as yet far from well understood; the difference in those results may be related to many specific conditions since in every study the synthesis method of LDHs and the water environment tested and coexisting anions all could be very different.

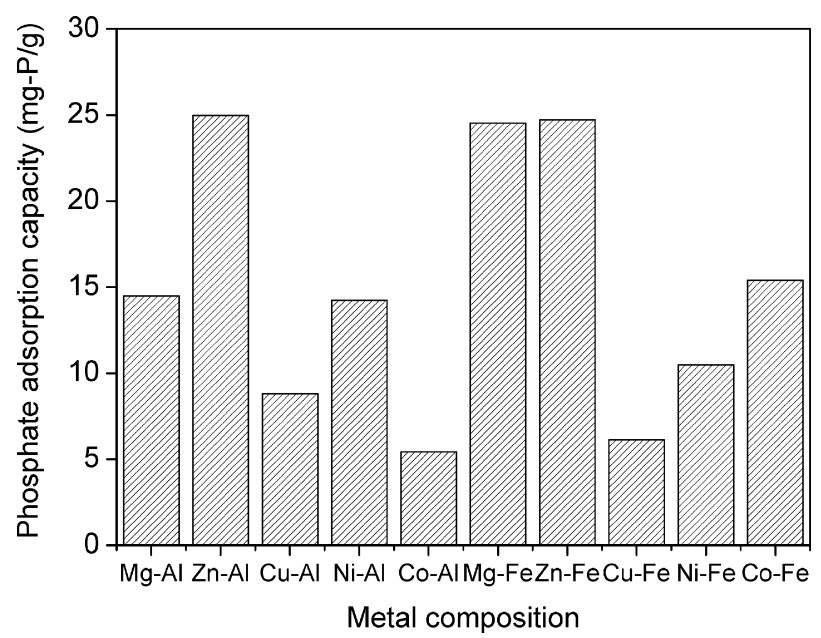

Fig. 1. Effect of metal composition of LDHs on phosphate adsorption from sewage sludge filtrate. $\mathrm{M}(\mathrm{II}) / \mathrm{M}(\mathrm{III})$ molar ratio of 2 was used to prepare these LDHs.

\subsection{2. $\mathrm{Zn} / \mathrm{Al}$ molar ratio}

In order to investigate the effect of $\mathrm{Zn} / \mathrm{Al}$ molar ratio on phosphate uptake, five different $\mathrm{Zn}-\mathrm{Al} \mathrm{LDHs}$ were used in adsorption assays. $\mathrm{A} \mathrm{Zn} / \mathrm{Al}$ ratio of 2 appeared optimal for phosphate adsorption by LDHs; more $\mathrm{Zn}^{2+}$ replacement by $\mathrm{Al}^{3+}$ (e.g. $\mathrm{Zn} / \mathrm{Al}$ of $1: 1$ or $1: 2$ ) decreased the adsorption capacity instead of further improvement (Fig. 2). Optimal results for other metal combinations have been reported elsewhere: $\mathrm{Mg} / \mathrm{Al}$ of 2:1 [19], $\mathrm{Mg} / \mathrm{Mn}$ of 3:1 [21] and $\mathrm{Ni} / \mathrm{Al}$ of 3:1 [24]. Phosphate adsorption activity of LDHs compounds results from the positively charged hydroxylated sheet, which is developed by partial substitution of trivalent for divalent cations. In this study, introduction of more $\mathrm{Al}^{3+}$ would improve the net positive charge of the mixed metal hydroxide layers and subsequently the phosphate adsorption. On the other hand, this may also lead to disorder of the layered hydrotalcite-like structure of LDHs or even phase change due to the radius difference between $\mathrm{Zn}$ and $\mathrm{Al}$, and cause the decrease in phosphate uptake [25].

\subsubsection{Calcination}

Calcined products of Zn-Al LDHs (CLDHs) generally had a higher adsorption capability as shown in Fig. 3. The greatest phosphate uptake ( $40.77 \mathrm{mg} \mathrm{P} / \mathrm{g}$ ) was observed when the adsorbent was calcinated at $300^{\circ} \mathrm{C}$. The adsorption was 1.55 -fold higher than that of the uncalcined material. Beyond this temperature, the adsorption

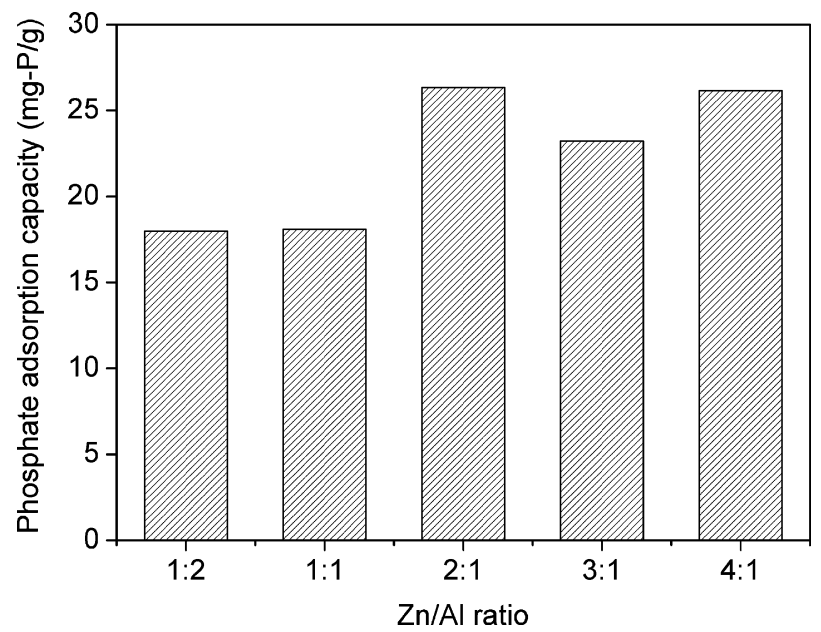

Fig. 2. Effect of $\mathrm{Zn} / \mathrm{Al}$ molar ratio on phosphate adsorption from sewage sludge filtrate. 


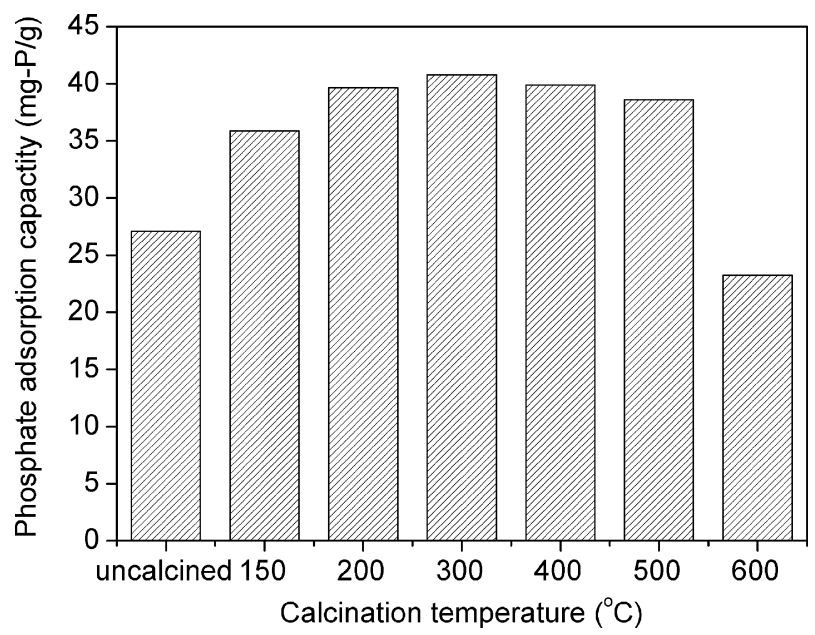

Fig. 3. Effect of calcination temperature on phosphate adsorption by LDHs from sewage sludge filtrate.

capacity of CLDHs went down slightly, with a sharp decrease after calcination at $600^{\circ} \mathrm{C}$. The improvement in adsorption of anions by LDHs calcination has also been addressed previously. For example, Mandal and Mayadevi reported that the fluoride uptake was increased by $21.2 \%$ after calcination of the $\mathrm{Zn}-\mathrm{Al} \mathrm{LDHs}$ at $450-500^{\circ} \mathrm{C}$ [26]. Carja et al. found that calcination $\left(450^{\circ} \mathrm{C}\right)$ markedly increased the removal efficiency of $\mathrm{As}(\mathrm{V})$ oxyanions up to $>90 \%$ for all the Fe-containing LDHs tested [27].

Some thermally decomposed LDHs will undergo spontaneous rehydration and structural reconstruction, called "Memory Effect", when added to an aqueous medium [28]. Anion incorporation occurs simultaneously in this process, increasing the anionic exchange capacity of this compound [29]. XRD pattern indicates that the LDHs phase completely disappeared and was replaced by phases of metal oxides after calcination at $300^{\circ} \mathrm{C}$ for $4 \mathrm{~h}$ (Fig. 4). The result is in accordance with that of TG-DSC analysis (data not shown), in which the first stage of mass loss of $~ 17 \%$ was observed with the temperature increasing to $300^{\circ} \mathrm{C}$. This phase transformation was obviously responsible for the marked increase in phosphate adsorption by CLDHs for the following three reasons: (1) a higher surface area was obtained in calcined particles, (2)

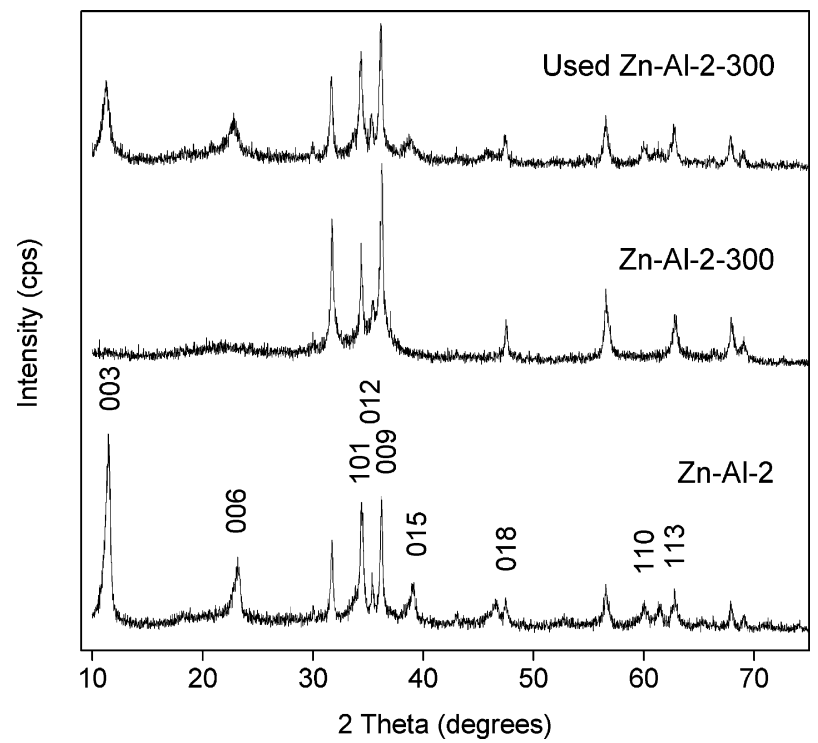

Fig. 4. XRD patterns of $\mathrm{Zn}-\mathrm{Al}-2, \mathrm{Zn}-\mathrm{Al}-2-300$, and $\mathrm{Zn}-\mathrm{Al}-2-300$ after phosphate adsorption.

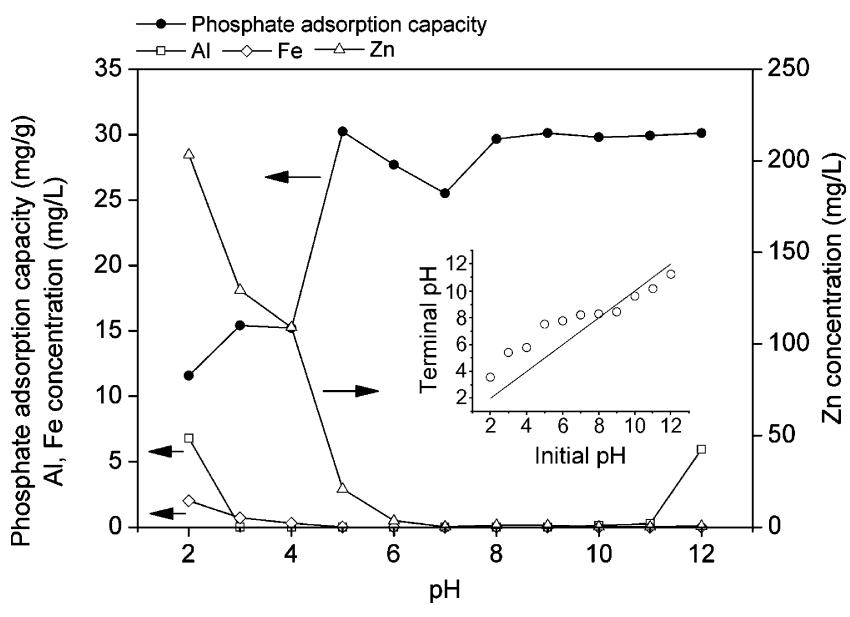

Fig. 5. Effect of $\mathrm{pH}$ on phosphate adsorption by $\mathrm{Zn}-\mathrm{Al}-2-300$ from sewage sludge filtrate. The inset shows a buffer effect by the LDHs addition.

obstacle anions (mainly $\mathrm{CO}_{3}{ }^{2-}$ ) were released from the precursor, producing more active sites for phosphate adsorption and (3) phosphate incorporation occurred during the LDHs reconstruction. However, a higher calcination temperature did not lead to further improvement in phosphate uptake. It can be explained by the fact that a mixture of $\mathrm{ZnO}$ and spinel-type $\mathrm{ZnAl}_{2} \mathrm{O}_{4}$ was formed under high temperatures instead of a metastable phase in the first stage, only which may reconstruct under appropriate conditions (Fig. 4). In addition, the specific surface area started to decline because of sintering when the temperature went beyond $300^{\circ} \mathrm{C}$ (data not shown), which would have weakened the surface adsorption. The used $\mathrm{Zn}-\mathrm{Al}-2-300$ had the same type of XRD pattern with the uncalcined $\mathrm{Zn}-\mathrm{Al} \mathrm{LDHs}$ indicating the layered structure was recovered after adsorbing phosphate from the sludge filtrate (Fig. 4). However, the crystallinity was lowered attested by the broadening of the diffraction peaks and the decrease in their intensity. This may be due to the high impurity in the waste stream.

\subsection{4. $p H$}

$\mathrm{pH}$ of a solution generally plays an important role in the physicochemical reaction at the water-solid interface. In addition, phosphate dissociation equilibria in liquid are $\mathrm{pH}$-related, which can be presented as [30]:

$\mathrm{H}_{3} \mathrm{PO}_{4} \stackrel{K_{1}}{\longleftrightarrow} \mathrm{H}_{2} \mathrm{PO}_{4}{ }^{-}+\mathrm{H}^{+} \stackrel{K_{2}}{\longleftrightarrow} \mathrm{HPO}_{4}{ }^{2-}+2 \mathrm{H}^{+} \stackrel{K_{3}}{\longleftrightarrow} \mathrm{PO}_{4}{ }^{3-}+3 \mathrm{H}^{+}$

where $\mathrm{p} K_{1}=2.15, \mathrm{p} K_{2}=7.20$ and $\mathrm{p} K_{3}=12.33$, respectively. In Fig. 5, a buffer effect of $\mathrm{pH}$ and LDHs dissolution were observed under acidic and highly alkaline conditions due to the amphoteric character of aluminum hydroxide. An acidic environment with a $\mathrm{pH}$ below 5 adversely affected phosphate uptake by the absorbent due to the significant LDH dissolution as indicated by a sharp increase of $\mathrm{Zn}^{2+}$ in bulk water. Increased phosphate removal at $\mathrm{pH} 5$, however, was attributed to a coagulation process with $\mathrm{Al}^{3+}$ ions from partial dissolution of the LDHs compound.

High adsorption capacity of $\sim 30 \mathrm{mg} \mathrm{P} / \mathrm{g}$ was achieved when the $\mathrm{pH}$ of the solution was above 8 . A slight decrease in the adsorption capacity of the LDHs occurred in the circumneutral environment possibly resulting from the weakening of its electrostatic interaction with phosphate, which transformed from a divalent to a monvalent ion. Based on these results it appears that $\mathrm{Zn}-\mathrm{Al}-2-300$ could be used as an effective adsorbent for phosphate recovery from sewage sludge filtrate and other phosphate-rich effluents with pHs ranging from 5 to 10 . 

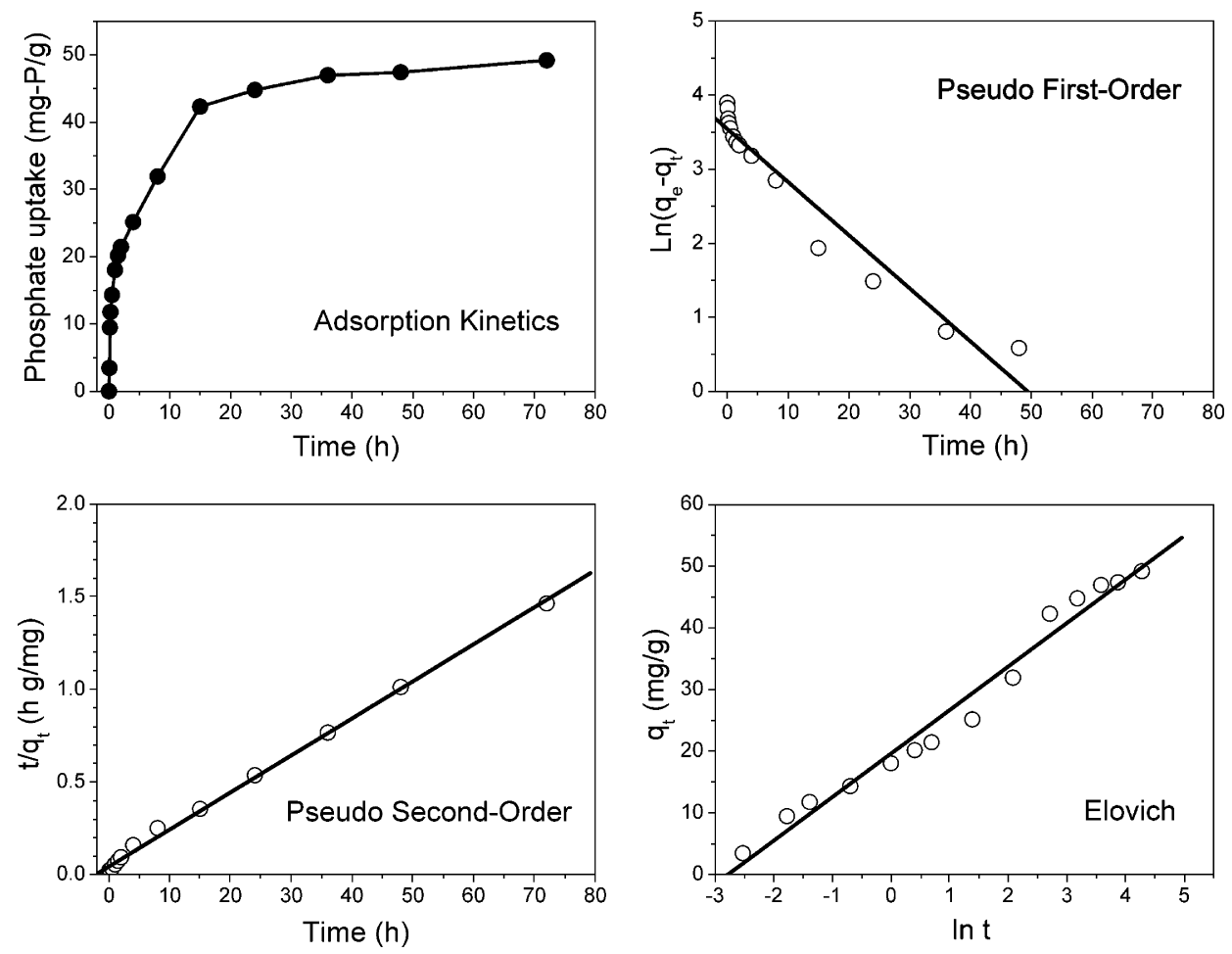

Fig. 6. Kinetics of phosphate adsorption on Zn-Al-2-300 from sewage sludge filtrate and data fitting by pseudo-first-order, pseudo-second-order and Elovich models.

\subsection{Adsorption kinetics}

According to Fig. 6, the majority of phosphate adsorption from sludge filtrate was completed in $24 \mathrm{~h}$. The phosphate adsorption capacity of $\mathrm{Zn}-\mathrm{Al}-2-300$ at equilibrium could be obtained in approximately $72 \mathrm{~h}$ and is estimated to be $50 \mathrm{mg} \mathrm{P} / \mathrm{g}$. The kinetics data were analyzed using pseudo-first-order, [35] pseudosecond-order [36] and Elovich models [37] (Fig. 6). Though a high correlation coefficient $\left(R^{2}>0.9\right)$ is obtained in each model, the phosphate adsorption in the present study most closely followed pseudo-second-order kinetics, by which a very accurate estimation of $q_{\mathrm{e}}$ is achieved as well as the highest correlation coefficient $\left(R^{2}>0.99\right)$ (Table 3$)$. Comparable results were observed in phosphate adsorption onto $\mathrm{ZnCl}_{2}$ activated coir pith carbon [31], calcined electrocoagulated metal hydroxides sludge [32], amorphous zirconium hydroxide [14] and dolomite [33].

\subsection{Adsorption isotherm}

Adsorption isotherms of phosphate on $\mathrm{Zn}-\mathrm{Al}$ CLDHs at different temperatures are presented in Fig. 7. At the same equilibrium concentration of phosphate in the sludge filtrate, the adsorption capacity of the LDHs increased with an increase in water temperature in the range from 25 to $30^{\circ} \mathrm{C}$. However, in the $50^{\circ} \mathrm{C}$ test the adsorption capacity approximated that found in the $25^{\circ} \mathrm{C}$ test. This

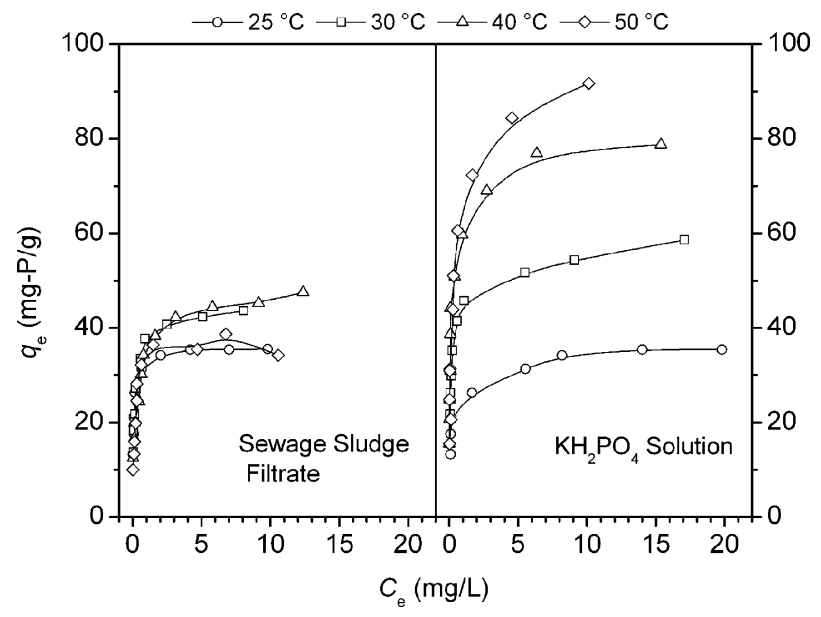

Fig. 7. Isotherms of phosphate adsorption on $\mathrm{Zn}-\mathrm{Al}-2-300$ from sewage sludge filtrate and $\mathrm{KH}_{2} \mathrm{PO}_{4}$ solution. The $\mathrm{KH}_{2} \mathrm{PO}_{4}$ solutions had the same phosphorus concentration as in the sludge filtrate: $20 \mathrm{mg} \mathrm{P} / \mathrm{L}$.

result may be due to the microorganisms existing in the sludge filtrate, which could have exhibited higher activity and consumed a portion of phosphate under a mesothermal environment, therefore lowering the contribution of adsorption in phosphate removal. In

Table 3

Kinetic models for phosphate adsorption on calcined Zn-Al LDHs from sludge filtrate and the calculated constants

\begin{tabular}{|c|c|c|c|c|}
\hline Model & Equation & Simplified form & Constant & $R^{2}$ \\
\hline Pseudo-first-order & $\frac{\mathrm{d} q_{\mathrm{t}}}{\mathrm{d} t}=k_{1}\left(q_{\mathrm{e}}-q\right)$ & $\ln \left(q_{\mathrm{e}}-q_{t}\right)=\ln \left(q_{\mathrm{e}}\right)-\frac{k_{1}}{2.303} t$ & $q_{\mathrm{e}}=34.6, k_{1}=0.165$ & 0.945 \\
\hline Pseudo-second-order & $\frac{\mathrm{d} q_{t}}{\mathrm{~d} t}=k_{2}\left(q_{\mathrm{e}}-q_{t}\right)^{2}$ & $\frac{t}{q_{t}}=\frac{1}{k_{2} q_{\mathrm{e}}^{2}}+\frac{t}{q_{\mathrm{e}}}$ & $q_{\mathrm{e}}=50.0, k_{2}=0.00913$ & 0.997 \\
\hline Elovich & $\frac{\mathrm{d} q_{t}}{\mathrm{~d} t}=\alpha \exp \left(-\beta q_{t}\right)$ & $q_{t}=\frac{1}{\beta} \ln (\alpha \beta)+\frac{1}{\beta} \ln (t)$ & $\alpha=113, \beta=0.142$ & 0.976 \\
\hline
\end{tabular}

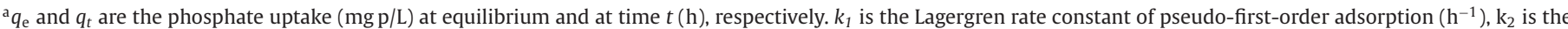
equilibrium rate constant of pseudo-second-order adsorption $(\mathrm{g} / \mathrm{mg} \mathrm{h}), \alpha$ and $\beta$ are constants of Elovich equation.

${ }^{\mathrm{b}}$ Constants in pseudo-second-order and Elovich equation were calculated without using $q_{0}\left(t=0, q_{0}=0\right)$. 
$\mathrm{KH}_{2} \mathrm{PO}_{4}$ solutions, only a clear improvement in phosphate uptake at equilibrium was observed with the gradual temperature increase. These results revealed that phosphate adsorption is an endothermic process. Furthermore, the significantly higher adsorption capacity obtained when using pure phosphate solutions, compared with that in sludge filtrate tests, at temperatures beyond $30^{\circ} \mathrm{C}$ demonstrated the enhancement of biological activity in the sludge filtrate.

Langmuir and Freundlich models were introduced to study the adsorption isotherms. The linear form of the Langmuir equation is represented as:

$\frac{C_{\mathrm{e}}}{q_{\mathrm{e}}}=\frac{1}{b q_{\mathrm{m}}}+\frac{C_{\mathrm{e}}}{q_{\mathrm{m}}}$

where $C_{\mathrm{e}}(\mathrm{mg} / \mathrm{L})$ is the phosphate concentration at equilibrium, $q_{\mathrm{e}}(\mathrm{mg} / \mathrm{L})$ the corresponding adsorption capacity, $q_{\mathrm{m}}(\mathrm{mg} / \mathrm{g})$ the maximum adsorption capacity and $b(\mathrm{~L} / \mathrm{mg})$ the affinity coefficient [31]. The essential characteristics of the Langmuir model can be described by a dimensionless constant called the equilibrium parameter $R_{\mathrm{L}}$,

$R_{\mathrm{L}}=\frac{1}{1+b C_{0}}$

where $C_{0}$ is the initial concentration of phosphate in solutions. The logarithmic form of Freundlich equation is represented as:

$\ln q_{\mathrm{e}}=\ln K_{f}+\frac{1}{n} \ln C_{\mathrm{e}}$

where $q_{\mathrm{e}}(\mathrm{mg} / \mathrm{g})$ is the corresponding adsorption capacity, $C_{\mathrm{e}}(\mathrm{mg} / \mathrm{L})$ the phosphate concentration at equilibrium, $K_{\mathrm{f}}$ and $n$ are constants.

The results of fitting the experimental data to the two models are presented in Table 4 . The Langmuir model clearly exhibits a better fit for phosphate adsorption on the calcined LDHs compared to the Freundlich model. In assays of both pure $\mathrm{KH}_{2} \mathrm{PO}_{4}$ solution and sludge filtrate, very high correlation coefficients $\left(R^{2}>0.99\right)$ were observed when using the Langmuir model.

\subsection{Phosphate desorption and LDHs regeneration}

Assays of phosphate desorption were conducted using three types of solutions as shown in Table 2 . $\mathrm{NaCl}$ solution was not suitable for exchanging $\mathrm{PO}_{4}{ }^{3-}$ from P-loaded $\mathrm{Zn}-\mathrm{Al}$ LDHs even at high concentration (20 wt\%) when compared with the other two desorption solutions. Kuzawa et al. [13] used $30 \mathrm{wt} \% \mathrm{NaCl}$ solution to elute phosphate from granular $\mathrm{Mg}-\mathrm{Al} \mathrm{LDHs}$ and the desorption rate was even lower (14\%). These results were expected due to the relatively low affinity of $\mathrm{Cl}^{-}$with LDHs compounds [21]. More than $80 \%$ of the phosphate on the LDHs can be desorbed by $\mathrm{NaOH}$ or $\mathrm{NaCO}_{3}$ solution with concentrations of $5 \mathrm{wt} \%$ and $10 \mathrm{wt} \%$, respectively. Unfortunately, carbonate anion acts as an obstacle to phosphate uptake by LDHs because of its high selectivity [34].

\section{Table 4}

Langmuir and Freundlich constants for phosphate adsorption on calcined $\mathrm{Zn}-\mathrm{Al}$ LDHs from sewage sludge filtrate.

\begin{tabular}{|c|c|c|c|c|c|c|c|}
\hline \multirow[t]{2}{*}{ Temp. $\left({ }^{\circ} \mathrm{C}\right)$} & \multicolumn{4}{|c|}{ Langmuir equation } & \multicolumn{3}{|c|}{ Freundlich equation } \\
\hline & $q_{\max }$ & $b$ & $R_{\mathrm{L}}$ & $R^{2}$ & $K_{\mathrm{f}}$ & $n$ & $R^{2}$ \\
\hline \multicolumn{8}{|c|}{ Sludge filtrate (initial phosphate concentration: around $20 \mathrm{mg} / \mathrm{L}$ ) } \\
\hline 25 & 35.81 & 13.64 & 0.003450 & 1.0000 & 28.32 & 6.436 & 0.8461 \\
\hline 30 & 44.11 & 6.495 & 0.006947 & 0.99 & 32.48 & 4.658 & 0.8796 \\
\hline 40 & 47.82 & 3.114 & 0.01580 & 0.99 & 30.08 & 4.239 & 0.9340 \\
\hline 50 & 35.73 & 12.77 & 0.004855 & 0.9955 & 27.11 & 4.606 & 0.7928 \\
\hline \multicolumn{8}{|c|}{$\mathrm{KH}_{2} \mathrm{PO}_{4}$ solution (initial phosphate concentration: $20 \mathrm{mg} / \mathrm{L}$ ) } \\
\hline 25 & 35.85 & 3.094 & 0.01590 & 0.9988 & 23.79 & 6.490 & 0.9123 \\
\hline 30 & 58.22 & 3.993 & 0.01237 & 0.9980 & 40.28 & 6.362 & 0.9250 \\
\hline 40 & 79.08 & 6.962 & 0.007131 & 0.9993 & 55.14 & 4.980 & 0.9293 \\
\hline 50 & 92.58 & 4.250 & 0.01163 & 0.9972 & 58.37 & 4.059 & 0.8632 \\
\hline
\end{tabular}

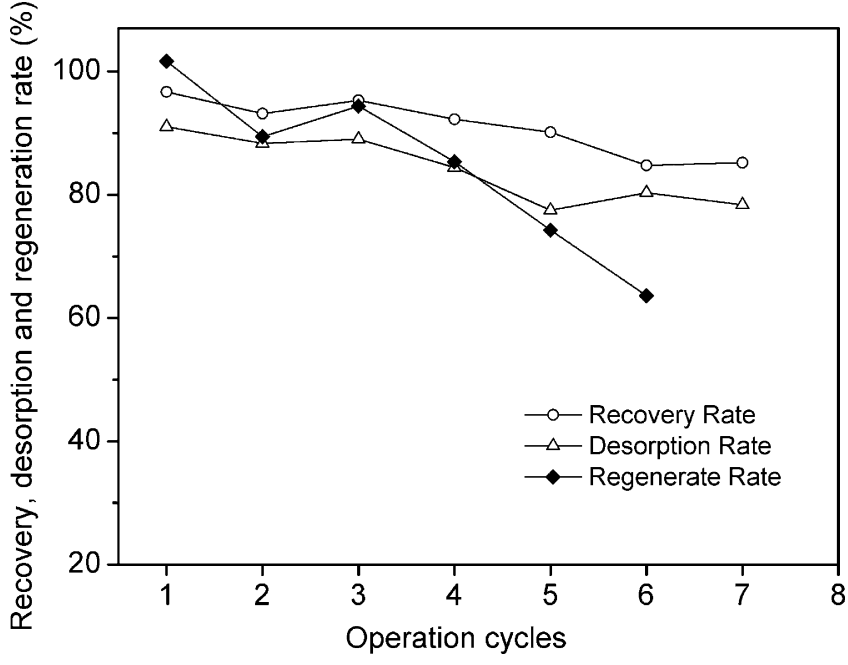

Fig. 8. Recovery, desorption and regeneration rates of $\mathrm{Zn}-\mathrm{Al}-2-300$ in the cycle assays.

Therefore, using $\mathrm{NaCO}_{3}$ in the desorption step introduces a challenge to the regeneration of the used LDHs. On the other hand, $\mathrm{CO}_{3}{ }^{2-}$ in the desorption solution makes it impossible to recover the enriched phosphorus as calcium phosphate. A higher desorption rate of phosphate was achieved with an increasing concentration of $\mathrm{NaOH}$ solution as the desorbent, however, LDHs dissolution can not be overlooked at $\mathrm{NaOH}$ concentrations beyond $5 \mathrm{wt} \%$, as indicated by the elevated levels of metal cations in the liquid phase (Table 2). No previous research has as yet addressed this phenomenon; however, the stability and activity of Al-containing LDHs compounds in each step of phosphate adsorption/recovery need further investigation.

A series of seven cycles of adsorption, desorption and regeneration were conducted to estimate the reusability of $\mathrm{Zn}-\mathrm{Al}-2-300$ during phosphate recovery from sewage sludge filtrate. Fig. 8 illustrates that the rates of LDHs particle recovery and phosphate desorption remained above $80 \%$ throughout seven cycles of operation. The regeneration rate was approximately $60 \%$ after six cycles indicating the accumulation of some interfering substance. The expiration of LDHs seemed slightly faster than in other studies (e.g., regeneration rate of almost $80 \%$ after six cycles [13]). This is probably due to lager quantities of impurities and coexisting ions contained in the real sludge filtrate vs. that found in pure phosphate solutions, which interfered with phosphate adsorption by binding a portion of the active sites on the LDHs.

\section{Conclusions}

Magnetic particles of layered double hydroxides were used in this study in order to separate and recover phosphate from sludge filtrate from Taiping municipal wastewater treatment plant in Harbin, China. $\mathrm{Zn}-\mathrm{Al} \mathrm{LDHs}$ with $\mathrm{Zn} / \mathrm{Al}$ molar ratio of 2 was found to be more efficient for phosphate adsorption in comparison to the other LDHs synthesized. Calcination remarkably improved phosphate adsorption by $\mathrm{Zn}-\mathrm{Al}-2$ because of the phosphate incorporation which occurred in the spontaneous rehydration and structural reconstruction of the calcined LDHs. After calcination at $300{ }^{\circ} \mathrm{C}$ for $4 \mathrm{~h}$, a phosphate adsorption capacity of $40.77 \mathrm{mg} \mathrm{P} / \mathrm{g}$ adsorbent was achieved. An acidic or highly alkaline environment adversely affected phosphate adsorption by $\mathrm{Zn}-\mathrm{Al}-2-300$ since aluminum hydroxide is amphoteric. Kinetics of phosphate adsorption from sewage sludge filtrate in this study followed a pseudo-second-order model. Adsorption isotherms indicated that 
phosphate uptake by $\mathrm{Zn}-\mathrm{Al}-2-300$ was an endothermic process and fitted the Langmiur model well. Phosphate desorption from LDHs particles can be effectively realized by using $5 \mathrm{wt} \%$ of $\mathrm{NaOH}$ solution, and a regeneration rate of $\sim 60 \%$ was observed after six operation cycles. Thus, despite of the complexity of the micro-process involved, phosphate adsorption and recovery from sewage sludge filtrate by using optimized layered double hydroxides appears to be a promising nutrient removal technology.

\section{Acknowledgements}

This work was supported by High-Tech Research and Development Program of China (863 Program, Grant No. 2007AA06Z328) and National Eleventh Five-Year Research Program of China (Grant No. 2006BAD03A0201).

\section{References}

[1] D. Mulkerrins, A.D.W. Dobson, E. Colleran, Parameters affecting biological phosphate removal from wastewaters, Environment International 30 (2004) 249-259.

[2] J. Driver, D. Lijmbach, I. Steen, Why recover phosphorus for recycling, and how? Environmental Technology 20 (1999) 651-662.

[3] L. Pastor, D. Mangin, R. Barat, A. Seco, A pilot-scale study of struvite precipitation in a stirred tank reactor: conditions influencing the process, Bioresource Technology (2008) 6285-6291.

[4] Y. Jaffer, T.A. Clark, P. Pearce, S.A. Parsons, Potential phosphorus recovery by struvite formation, Water Research 36 (2002) 1834-1842.

[5] L. Zeng, X. Li, J. Liu, Adsorptive removal of phosphate from aqueous solutions using iron oxide tailings, Water Research 38 (2004) 1318-1326.

[6] A. Ugurlu, B. Salman, Phosphorus removal by fly ash, Environment International 24 (1998) 911-918

[7] B. Kostura, H. Kulveitová, J. Leško, Blast furnace slags as sorbents of phosphate from water solutions, Water Research 39 (2005) 1795-1802.

[8] W. Huang, S. Wang, Z. Zhu, L. Li, X. Yao, V. Rudolph, F. Haghseresht, Phosphate removal from wastewater using red mud, Journal of Hazardous Materials 158 (2008) 35-42.

[9] Z. Hongshao, R. Stanforth, Competitive adsorption of phosphate and arsenate on goethite, Environmental Science \& Technology 35 (2001) 47534757.

[10] A. Ler, R. Stanforth, Evidence for surface precipitation of phosphate on goethite, Environmental Science \& Technology 37 (2003) 2694-2700.

[11] S. Karaca, A. Gürses, M. Ejder, M. Açıkyıldız, Adsorptive removal of phosphate from aqueous solutions using raw and calcinated dolomite, Journal of Hazardous Materials 128 (2006) 273-279.

[12] M. Özacar, Adsorption of phosphate from aqueous solution onto alunite, Chemosphere 51 (2003) 321-327.

[13] K. Kuzawa, Y.J. Jung, Y. Kiso, T. Yamada, M. Nagai, T.G. Lee, Phosphate removal and recovery with a synthetic hydrotalcite as an adsorbent, Chemosphere 62 (2006) 45-52.

[14] R. Chitrakar, S. Tezuka, A. Sonoda, K. Sakane, K. Ooi, T. Hirotsu, Selective adsorption of phosphate from seawater and wastewater by amorphous zirconium hydroxide, Journal of Colloid and Interface Science 297 (2006) 426433.

[15] D. Zhao, K. Sengupta, Selective removal and recovery of phosphate in a novel fixedbed process, Water Science and Technology 33 (1996) 139-147.
[16] T. Kwon, G.A. Tsigdinos, T.J. Pinnavaia, Pillaring of layered double hydroxides (LDH's) by polyoxometalate anions, Journal of the American Chemical Society 110 (1988) 3653-3654

[17] A. Ookubo, K. Ooi, H. Hayashi, Preparation and phosphate ion-exchange properties of a hydrotalcite-like compound, Langmuir 9 (1993) 1418-1422.

[18] M. Badreddine, A. Legrouri, A. Barroug, A. De Roy, J.P. Besse, Ion exchange of different phosphate ions into the zinc-aluminium-chloride layered double hydroxide, Materials Letters 38 (1999) 391-395.

[19] J. Das, B.S. Patra, N. Baliarsingh, K.M. Parida, Adsorption of phosphate by layered double hydroxides in aqueous solutions, Applied Clay Science 32 (2006) 252-260.

[20] Y. Seida, Y. Nakano, Removal of phosphate by layered double hydroxides containing iron, Water Research 36 (2002) 1306-1312.

[21] R. Chitrakar, S. Tezuka, A. Sonoda, K. Sakane, K. Ooi, T. Hirotsu, Adsorption of phosphate from seawater on calcined MgMn-layered double hydroxides, Journal of Colloid and Interface Science 290 (2005) 45-51.

[22] A.M. Farmer, Reducing phosphate discharges: the role of the 1991 EC urban wastewater treatment directive, Water Science and Technology 44 (2001) 41-48.

[23] APHA, AWWA, WEF, Standard Methods for the Examination of Water and Wastewater, 20 ed., American Public Health Association, Washington, DC, 1998.

[24] Y. Wang, H. Gao, Compositional and structural control on anion sorption capability of layered double hydroxides (LDHs), Journal of Colloid and Interface Science 301 (2006) 19-26.

[25] Z.P. Xu, H.C. Zeng, Abrupt Structural Transformation in Hydrotalcite-like Compounds $\mathrm{Mg}_{1-x} \mathrm{Al}_{x}(\mathrm{OH})_{2}\left(\mathrm{NO}_{3}\right)_{x} \cdot n \mathrm{H}_{2} \mathrm{O}$ as a continuous function of nitrate anions, Journal of Physical Chemistry B 105 (2001) 1743-1749.

[26] S. Mandal, S. Mayadevi, Adsorption of fluoride ions by $\mathrm{Zn}-\mathrm{Al}$ layered double hydroxides, Applied Clay Science 40 (2008) 54-62.

[27] G. Carja, S. Ratoi, G. Ciobanu, I. Balasanian, Uptake of $\mathrm{As}(\mathrm{V})$ from aqueous solution by anionic clays type FeLDHs, Desalination 223 (2008) 243-248.

[28] O.P. Ferreira, O.L. Alves, D.X. Gouveia, A.G. Souza Filho, J.A.C. de Paiva, J.M. Filho, Thermal decomposition and structural reconstruction effect on $\mathrm{Mg}-\mathrm{Fe}$ based hydrotalcite compounds, Journal of Solid State Chemistry 177 (2004) 3058-3069.

[29] L. Châtelet, J.Y. Bottero, J. Yvon, A. Bouchelaghem, Competition between monovalent and divalent anions for calcined and uncalcined hydrotalcite: anion exchange and adsorption sites, Colloids and Surfaces A: Physicochemical and Engineering Aspects 111 (1996) 167-175.

[30] D.D. Perrin, B. Dempsey, Buffers for pH and Metal Ion Control, Chapman and Hall, London, 1974.

[31] C. Namasivayam, D. Sangeetha, Equilibrium and kinetic studies of adsorption of phosphate onto $\mathrm{ZnCl}_{2}$ activated coir pith carbon, Journal of Colloid and Interface Science 280 (2004) 359-365.

[32] A.K. Golder, A.N. Samanta, S. Ray, Removal of phosphate from aqueous solutions using calcined metal hydroxides sludge waste generated from electrocoagulation, Separation and Purification Technology 52 (2006) 102-109.

[33] S. Karaca, A. Gürses, M. Ejder, M. Açıkyıldız, Kinetic modeling of liquid-phase adsorption of phosphate on dolomite, Journal of Colloid and Interface Science 277 (2004) 257-263.

[34] M. Badreddine, M. Khaldi, A. Legrouri, A. Barroug, M. Chaouch, A. De Roy, J.P. Besse, Chloride-hydrogenophosphate ion exchange into the zinc-aluminiumchloride layered double hydroxide, Materials Chemistry and Physics 52 (1998) 235-239.

[35] S. Lagergren, About the theory of so-called adsorption of soluble substances, Kungliga Svenska Vetenskapsakademiens Handlingar 24 (1898) 1-39.

[36] Y.S. Ho, Adsorption of heavy metals from waste streams by peat, Ph. D. Thesis, University of Birmingham, Birmingham, U.K., 1995.

[37] C. Aharoni, D.L. Sparks, S. Levinson, I. Ravina, Kinetics of soil chemical reactions: relationships between empirical equations and diffusion models, Soil Science Society of America Journal 55 (1991) 1307-1312. 